\title{
Effect of short-term fasting on plasma amino acids, glucose and insulin in non-pregnant and non-lactating Friesian cows
}

\author{
BB Ndibualonji, B Debue, D Dehareng, JM Godeau \\ Laboratoire de Biochimie normale et pathologique, faculté de Médecine vétérinaire, \\ boulevard de Colonster, 20 B42, B-4000 Liège-Sart Tilman, Belgium
}

Four mature cows $( \pm 516 \mathrm{~kg}$ ) were sampled at hourly intervals in the jugular vein from 1200 on $d 1$ to $0800 \mathrm{~h}$ on $\mathrm{d} 2$ (fed state: $20 \mathrm{~h}$ ) and from 1200 on $\mathrm{d} 2$ to 0800 $\mathrm{h}$ on $\mathrm{d} 3$ (fasting: $20 \mathrm{~h}$ ).

The first day, the cows received in 2 equal meals given at 06.15 and $15.303 \mathrm{~kg}$ meadow hay, $2.5 \mathrm{~kg}$ dried beet pulp and $1.8 \mathrm{~kg}$ concentrate diet, covering 1.3 times their energy and nitrogen maintenance requirements. On the second day, half of this ration was given at 06.15, after which only water was available. Plasma amino acids (PAA) were measured by HPLC, glucose (Glc) by the hexokinase method, and insulin (Ins) by RIA. Mean data were compared (Student's t-test, paired data).

Fasting resulted in slight increases in PAA that were significant for Ala, Gln and Ser. Both Glc $(P>0.05)$ and Ins $(P<0.01)$ concentrations decreased during fasting. This is in agreement with the results of De Boer et al (1985), who reported increased PAA in Holstein cows during early lactation. Similarly, Rule et al (1985) noticed decreased Ins concentrations after $24 \mathrm{~h}$ fast- ing in steers. The PAA increase indicates that the rate of AA entry into plasma exceeded their rate of withdrawal. The labile protein reserve could be an intermediate source of energy and serve as a gluconeogenesis (GN) precursor in order to avoid a drop in glycemia. The decline in Ins levels is thought to be involved in the increased release of $A A$ to the circulation and might have resulted in a decrease of both peripheral uptake of $A A$ and proteosynthesis, thereby making available more AA for GN.

In conclusion, changes in protein, Gic and Ins metabolism may be observed in short-term fasting $(20 \mathrm{~h})$ in dry cows. Ins seems to play a major role in protein metabolism during fed and fasting states.

De Boer G, Trenkle A, Young JW (1985) J Dairy Sci $68,326-337$

Rule DC, Beitz DC, De Boer G, Lyle RR, Trenkle AH, Young JW (1985) J Anim Sci 61, 868-875

Table I. Effect of fasting on PAA $(\mu \mathrm{mol} / \mathrm{l})$, Glc $(\mathrm{mg} / 100 \mathrm{ml})$ and $\mathrm{lns}(\mu \mathrm{U} / \mathrm{ml})$.

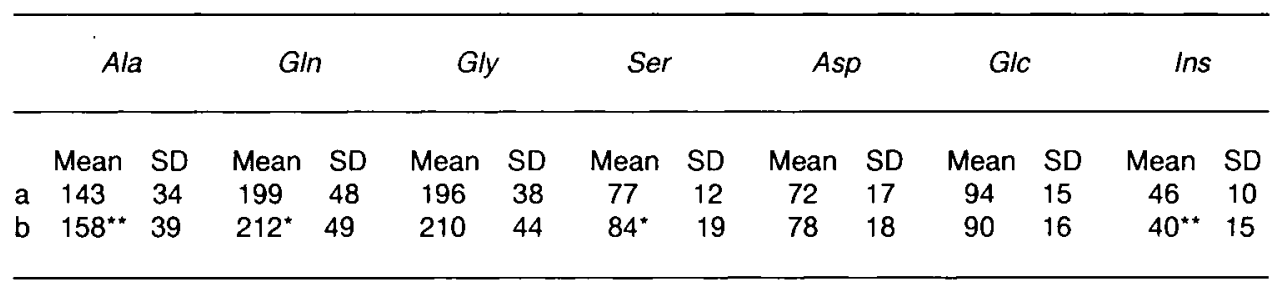

a Fed state $(20 \mathrm{~h})$; b Fasting $(20 \mathrm{~h}) ; * P<0.05 ;{ }^{* *} P<0.01$; SD: standard deviation. 